\title{
KONSEP ORGANISASI PENDIDIKAN DALAM PEMBERDAYAAN SEKOLAH
}

\section{Fitriyani}

Dosen STAI Bumi Silampari Lubuklinggau

fitriyani@staibsllg.ac.id

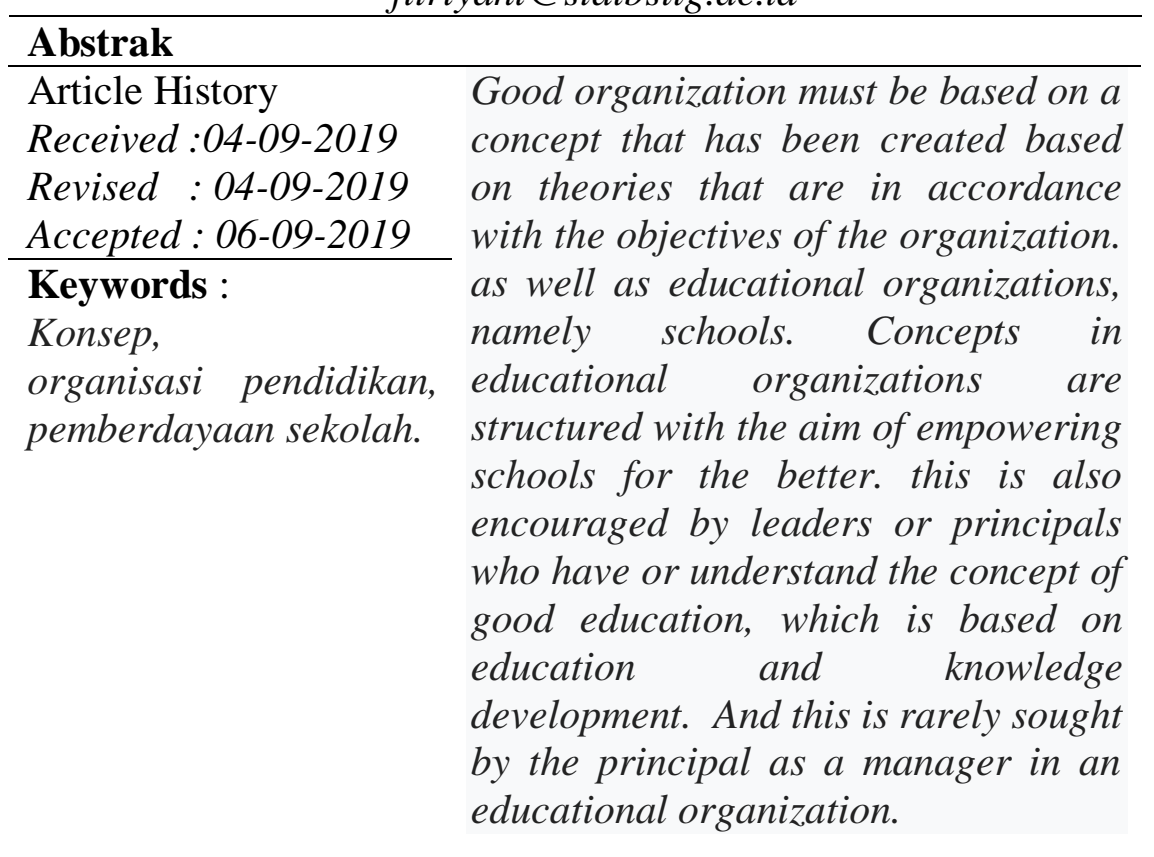

\section{Pendahuluan}

Sekolah merupakan salah satu tempat belajar para siswa yang memiliki kaitan dengan lingkungannya. Sebagai suatu sistem, sekolah merupakan organisasi terbuka yang tidak boleh mengisolasi diri dari lingkungannya, melainkan harus selalu mengadakan hubungan kontak dengan lingkungannya dan bekerja sama. Sekolah sebagai suatu sistem diorganisasikan untuk memudahkan pencapaian tujuan belajar dan mengajar yang berkualitas dalam melayani peserta didik secara efektif dan efisien. Organisasi dapat diartikan sebagai pemberian struktur/susunan, terutama dalam penempatan personal, yang dihubungkan dengan garis kekuasaan dan tanggung jawabnya didalam keseluruhan organisasi (Purwanto, 2005:128). Dalam organisasi susunan dan garis-garis kekuasaan serta tanggung jawab itu menentukan bentuk dan sifat organisasi itu secara keseluruhan. 
Sebagaimana firman Allah SWT dalam surat As-Saff : 4 (DEPAG RI, 2010:551) yang Terjemahannya: "Sesungguhnya Allah mencintai orang-orang yang berperang dijalannya dalam barisan yang teratur, mereka seakan-akan seperti suatu bangunan yang tersusun kokoh."(QS.As-Saff : 4)

Dalam surat ini terdapat konsep besar yang harus ada untuk mewujudkan organisasi yang kokoh yaitu kesesuaian konsep dan pelaksanaan dalam organisasi, soliditas tim, ketepatan mengukur dan mengetahui kekuatan dan tantangan, konsep kesungguhan dalam bekerja dan berjuang, serta memiliki kader yang solid. Secara teoritis, organisasi sekolah dalam menyelenggarakan programnya terlebih dahulu penyusunan tujuan dengan baik yang implementasinya dilakukan secara efisien dan efektif dalam proses belajar mengajar. Di dalam organisasi juga diperlukan adanya semangat organisasi dan organisasi ditentukan oleh sistem yang ada dalam organisasi dan kualitas sang pemimpin. Keefektifan organisasi sekolah tergantung pada desain organisasi dan pelaksanaan fungsi komponen organisasi yang mencakup proses pengelolaan informasi, partisifasi, perencanaan, pengawasan, dan pembuatan kebijakan dalam pelaksanaan tugas pokok.

Menurut Immegart (Sagala, 2004:56), sistem adalah suatu kesatuan yang utuh dengan bagian-bagiannya yang tersusun secara sistematis yang mempunyai relasi satu dengan yang lainnya sesuai dengan konteksnya. Berkaitan dengan hal ini, maka sebuah desain organisasi sekolah di dalamnya tim administrasi sekolah yang terdiri dari sekelompok orang yang bekerja sama dalam rangka mencapai tujuan organisasi. Tim administrasi ini bukan pegawai tata usaha, tetapi pihak-pihak yang dapat mengambil kebijakan berkaitan dengan manajemen sekolah. Tujuan utama tim administrasi ini adalah untuk mengembangkan prosedur kebijakan sekolah, memecahkan masalahmasalah umum mengenai sekolah dengan memanfaatkan semua potensi individu yang tergabung dalam tim.

Semua anggota tim sekolah harus dapat melakukan kerja sama dalam rangka mensukseskan program sekolah. Hal ini menunjukkan bahwa dalam stuktur organisasi sekolah, kepala sekolah bersama para guru merupakan orang yang paling bertanggung jawab melaksanakan program dan kegiatan sekolah. Pemberdayaan sekolah merupakan pilihan yang paling tepat untuk mewujudkan sekolah yang mandiri dan memiliki keunggulan tinggi. Sebagaimana firman Allah SWT 
dalam surat Ar-Rum : 30 (Depag RI, 2010:407). Terjemahannya: “ Maka hadapkanlah wajahmu dengan lurus kepada agama (Islam ), (sesuai) fitrah Allah disebabkan Dia telah menciptakan manusia menurut (fitrah) itu. Tidak ada perubahan pada ciptaannya Allah. Demikian itu Agama yang lurus, tetapi kebanyakan manusia tidak mengetahuinya. (QS.Ar-Rum : 30)

Sebagai duta Allah, manusia memiliki karakteristik yang multidimensi, yakni pertama, diberi hak untuk mengatur alam ini sesuai kapasitasnya. Kedua, manusia menempati posisi terhormat diantara makhluk Allah yang lain. Anugerah ini diperoleh lewat kedudukan, kualitas dan kekuatan yang diberikan Allah kepadanya. Ketiga manusia memiliki peran khusus yang harus dimainkan yaitu mengembangkan dunia sesuai dasar dan hukum-hukum yang ditetapkan oleh Allah. Kemampuan akal secara fitrah memotivasi manusia memahami simbol-simbol, hal-hal yang tidak nyata, menganalisa, membandingkan maupun menarik kesimpulan dan akhirnya membuat pillihan yang baik dan yang buruk serta yang benar dan yang salah. Disamping itu akal dapat memotivasi manusia berkreasi dan berinovasi dalam menciptakan kebudayaan serta peradaban (Syamsudin, 2016:9).

Prinsip pemberdayaan adalah memberikan otonomi yang lebih luas dalam memecahkan permasalahn di sekolah (Sagala, 2004:99). Dalam hal ini sekolah harus memiliki keunggulan yang tinggi dan memberikan otonomi yang luas kepada sekolah dalam menyelesaikan permasalahan disekolah. Keberhasilan kinerja sistem pendidikan bukan hanya ditunjang oleh tenaga kependidikan yang disebut guru saja, melainkan juga oleh tenaga kependidikan yang lainnya. Termasuk mereka yang berada pada kantor pendidikan (Dinas pendidikan provinsi maupun kabupaten/kota) (Bustomi, Vol II:61). Untuk memperkuat kinerja pendidikan bahwa pengakuan atas pentingnyaprofesi keguruan sama pentingnya dengan pengakuan terhadap disiplin ilmu manajemen pendidikan yang berdampingan dan saling menunjang dalam mewujudkan tujuan dan fungsi-fungsi pendidikan selain pengajaran dapat dilihat pada program ekstrakulikuler pada sekolah tersebut, seperti pengelolaan olah raga dan pengelolaan pengelaran kesenian yang ditangani secara profesional sampai sekolah menerima laporan bahwa masyarakat dan para orang tua merasa cukup senang dan puas atas program sekolah. 
Untuk mencapai sekolah yang baik dan berhasil, kepala sekolah bersama para guru dan staf saling membagi ide, saling membantu atau sama lainnya, tingkat perputaran atau pergantian guru karena mendapatkan sangsi adalah rendah, jumlah siswa berkasus mental termasuk dalam posisi rendah sekali dibanding dengan sekalah lainnya yang serupa. Artinya, sekolah yang berhasil menunjukkan bahwa guru dan para siswanya memiliki perilaku atau akhlak yang baik dan juga memiliki intelektualitas yang tinggi (Sagala, 2004:90)

\section{Metode}

Penulis dalam memberikan jawaban sesuai dengan fokus penelitian melalui metode kualitatif dengan kajian dokumen. Kajian dokumen dianggap sebagai analisis dokumen, yang terdiri buku, artikel, internet dan bahan-bahan yang sesuai dengan penelitian. Adapun cara-cara dalam pengumpulan datanya. Pertama, melalui kajian kepustakaan yang sesuai dengan bahan yang akan diteliti. Kedua, setelah datadata telah diperoleh oleh peneliti, maka selanjutnya menganalisis datanya melalui metode deskriptif sesuai dengan pemahaman penulis dalam melakukan kajian ini (Long, 2016).

\section{Pembahasan}

\section{Konsep Organisasi Pendidikan}

Kata "organisasi" secara etimologi berasal dari bahasa latin "organum yang berarti alat, sedangkan menurut istilah berasal dari bahasa Inggris organization berarti organisasi, penyusunan, pengumpulan, penghimpunan" (Taruna, 2017:12). Jadi organisasi adalah suatu susunan kesatuan-kesatuan kecil yang membentuk satu kesatuan besar. Sedangkan organisasi menurut pendapat para ahli adalah sebagai berikut:

a. Prajudi Atmosudirjo mengemukakan bahwa organisasi adalah "struktur tata pembagaian kerja dan struktur tata hubungan kerja antar kelompok orang-orang memegang posisi yang bekerja sama secara tertentu untuk bersama-sama untuk mencapai tujuan tertentu" (Fatoni, 2013:2).

b. W. J. S. Poerwadarminta mendefinisikan organisasi adalah "susunan dan aturan dari berbagai bagian (orang dan lain-lain) sehingga merupakan yang sistematis. 
c. Kochler mengemukakan bahwa organisasi adalah sistem interaksi yang terstruktur yang mengkoordinasikan usaha suatu klompok orang untuk mencapai tujuan tertentu.

d. Adapun menurut J. William Schulze,organisasi diartikan sebagai penggabunganalat-alat, benda-benda, perlengkapan, ruang kerja dan segala sesuatu yang berkaitan dengan organisasi, yang dikumpulkan dalam suatu hubungan yang sitematis dan efektif guna mencapai tujuan yang telah ditetapkan.

e. John Price Jones organisasi adalah struktur dan peralatan yang tersusun dari orang-orang dan benda-benda dimana suatu usaha berencana yang teratur dijalannya (Majalah Pendidikan, 2017:3).

f. Syaiful Sagala mendefinisikan organisasi adalah "institusi atau wadah tempat orang berinteraksi dan bekerjasama sebagai suatu unit terkoordinasi yang setidaknya terdiri dari setidaknya dua orang atau lebih yang berfungsi mencapai sasaran" (Taruna, 2017:15).

Dari beberapa pengertian para ahli di atas menunjukkan bahwa organisasi adalah sebuah wadah, tempat, sistem untuk melakukan kegiatan bersama untuk mencapai tujuan yang diinginkan. Sedangkan pengorganisasian merupakan proses pembentukan wadah/sistem dan penyusunan anggota dalam bentuk struktur organisasi untuk mencapai tujuan organisasi. Jika dihubungkan dengan pendidikan maka organisasi pendidikan adalah wadah untuk melakukan kegiatan pendidikan guna mencapai tujuan pendidikan yang diinginkan.

\section{Unsur-unsur dasar pembentuk suatu organisasi}

Unsur-unsur dasar pembentukan suatu organisasi menurut Ara Hidayat dan Imam Machali (Ara dan Imam, 2010:64) adalah sebagai berikut: a). Adanya tujuan bersama, organisasi mensyaratkan suatu yang akan diinginkan, biasanya terumuskan dalam visi, misi target, tujuan. Tujuan inilah menyatukan berbagai unsur dalam organisasi. b) Adanya kerja sama dua orang atau lebih untuk mewujudkan tujuan bersama. c) Adanya pembagian tugas, untuk efektifitas, efisiensi, dan produktivitas organisasi dibutuhkan pembagian tugas. d) Adanya kehendak untuk kerja sama, anggota organisasi mempunyai kemauan/kehendak untuk bekerja sama untuk tujuan bersama. Sekolah sebagai lembaga pendidikan sudah seharusnya mempunyai organisasi yang baik agar tujuan pendidikan formal bisa tercapai 
dengan maksimal. Unsur-unsur personal pendidikan adalah kepala sekolah, guru, karyawan,dan murid. Selain itu juga sekolah sebagai lembaga pendidikan formal yang berada di bawah instansi atasan baik itu kantor dinas atau kantor wilayah departemen yang bersangkutan.

Organisasi yang baik hendaknya membagi tugas-tugas dan tanggung jawab dengan sesuai kapasitas, fungsi dan wewenang serta kemampuannya untuk mencapai tujuan pendidikan. Melalui struktur organisasi yang ada anggota organisasi pendidikan akan mengetahui tugas dan wewenang semua steakholder pendidikan

\section{Tujuan dan Manfaat Organisasi Pendidikan}

Pendidikan sebagai organisasi harus dikelola sesuai dengan sumberdaya yang ada baik itu SDM maupun sarana dan prasarana, sehingga aktivitas pelaksanaan program organisasi dapat berjalan secara efektif dan efisien. Diantara manfaat tujuan organisasi pendidikan (Surya, 2004:140) adalah: Mengatasi keterbatasan kemampuan, kemauan dan sumber daya yang dimiliki dalam mencapai tujuan pendidikan. Terciptanya efektifitas dan efisiensi organisasi dalam rangka pencapaian tujuan pendidikan. Sebagai wadah pengembangan potensi dan spesialisasi yang dimiliki. Menjadi tempat pengembangan ilmu pengetahuan dan lain-lain.

\section{Jenis-jenis Organisasi Pendidikan}

Jenis-jenis organisasi pendidikan secara umum terbagi menjadi dua yaitu:

a. Organisasi Formal

Organisasi formal adalah organisasi yang dicirikan oleh struktur organisasi. Keberadaan struktur organisasi yang menjadi pembeda utama antara organisasi formal dan informal. Sebagai struktur organisasi formal dimaksudkan untuk menyediakan penugasan kewajiban dan tanggung jawab memperlihatkan hubungan tertentu antara personil-personil organisasi. Struktur dalam organisasi memperlihatkan unsur-unsur administrasi berikut:1).Kedudukan: Kedudukan struktur mengambarkan letak/posisi setiap orang dalam organisasi. 2).Hierarki dalam Kekuasan: struktur digambarkan sebagai suatu rangkaian hubungan antar satu orang dengan yang lainnya dalam suatu organisasi.3).Kedudukan garis dan staf: organisasi garis memperjelas struktur perintah, jalan permohonan, pengambilan 
keputusan, , saluran komunikasi, mengeluarkan instruksi, dan petunjuk pelaksanaan. Bentuk skema struktur organisasi formal dapat berbentuk piramida mendatar atau melingkar.

b. Organisasi Informal

Keberadaan organisasi dapat dilihat dari 3 karakteristik yaitu norma perilaku, tekanan untuk adaptasi dan kepemimpinan informal. Menurut Ara Hidayat dan Imam Machali norma prilaku adalah standar prilaku yang diharapkan menjadi perilaku bersama yang ditetapkan oleh kelompok, dalam sebuah kesepakatan bersama tidak tertulis di antara orang-orang dalam organisasi tertentu.

Tekanan untuk menyesuaikan diri akan muncul apabila seseorang akan bergabung dalam sebuah organisasi, tidak semata secara fisik melainkan melibatkan sosial emosional individu-individu. Kepemimpinan formal dalam organisasi informal menjadi salah satu kompon yang sangat kuat mempengaruhi orang-orang di dalam oeganisasi bahkan dimungkinkan melebihi kepemimpinan dalam organisasi formal, dimana seseorang dipatuhi bukan karena memiliki jabatan, tetapi ada kelebihan yang secaraa lamiah dan mampu mempengaruhi oranglain tanpa paksaan apapun.

Jenis-jenis organisasi memiliki jumlah yang tidak sedikit namun pada pelaksanaannya ada satu jenis organisasi yang paling urgen dan patut untuk dikaji yaitu jenis organisasi dilihat dari segi tujuannya (Ara dan Imam, 2010:66) :

a. Organisasi profil

Organisasi profil adalah organisasi yang tujuan didirikannya untuk mengambil keuntungan. Misalnya: perusahaan, koprasi, dan lain sebagainya.

b. Organisasi Non profil

Organisasi non profil adalah organisasi yang didirikan bukan untuk mencari keuntungan. Misalnya: LSM, ormas, sekolah, pesantren, dll.

Setiap lembaga atau satuan pendidikan memiliki tujuan dasar dalam pendidikan, hal ini tercantum dalam UU sisdiknas Tahun 2003 yang berbunyi ( UU RI, 2003:3) "Pendidikan diartikan sebagai suatu usaha sadar dan terencana untuk mewujudkan suasana belajar dan proses pembelajaran agar peserta didik secara aktif mengembangkan potensi dirinya untuk memiliki kekuatan spiritual keagamaan, pengendalian diri, kepribadian, kecerdasan, prilaku mulia, serta 
keterampilan yang diperlukan dirinya, masyarakat, bangsa dan negara".

\section{Struktur Organisasi dalam Pendidikan dan Pengajaran}

Struktur organisasi dalam pendidikan dan pengajaran ditiap negara berbeda-beda. Hal ini tergantung pada struktur organisasi dan administrasi pemerintah negara masing-masing. Di suatu negara yang bentuk dan struktur organisasi pemerintahannya cenderung ke arah kediktatoran, di mana segala kekuasaan dipusatkan pada satu orang atau segolongan orang. Struktur organisasi pendidikannya cenderung kearah sentralisasi. Setiap hal yang berkaitan dengan bidang pendidikan, ditentukan dan diselenggarakan oleh pusat secara sentral. Sebaliknya, dalam negara-negara yang menganut sistem demokrasi dalam pemerintahannya, struktur organisasi pendidikannya disususn menurut pola-pola yang demokratis. Kekuasaan dan penyelenggaraan pendidikan tidak dilakukan secara sentral, tetapi dibagi-bagikan atau diserahkan kepada daerah-daerah, disesuaikan dengan kondisi dan kepentingan daerah.

Struktur organisasi yang pokok ada dua macam yaitu sentralisasi dan desentralisasi. Di antara kedua struktur tersebut terdapat beberapa struktur campuran, yakni yang lebih cenderung kearah sentralisasi mutlak, dan lebih mendekati desentaralisasi tetapi beberapa bagaian masih dilakukans ecara sentral.

Struktur Sentralisasi

Di negara-negara yang organisasi pendidikannya dijalankan secara sentral, yakni yang kekuasaan dan tanggung jawabnya dipusatkan pada suatu badan di pusat pemerintahan, maka pemerintahan daerah kurang sekali atau sama sekali tidak mengambil bagian dalam adminstrasi apapun. Jika ada bagian-bagian yang dikerjakan oleh pemerintahan daerah atau wilayah-wilayah selanjutnya, semua merupakan pekerjaan-pekerjaan prantara, sebagai penyambung atau penyalur ketetapan-ketetapan-ketetapan dan instruksi-instruksi dari pusat untuk dilaksanakan di sekolah-sekolah. Di dalam struktur organisasi yang berbentuk organisasi line (line organization), garis-garis perintah/kekuasaan dan tanggung jawab membentang tegak lurus dari atas ke bawah atau dari pimpinan atasan sampai kepada organ yang paling bawah. Segala sesuatu yang mengenai urusan-urusan pendidikan, dari menetukan kebijakan (policy) dan perencanaan, penentuan struktur dan syarat-syarat 
personel, urusan kepegawaian, sampai kepada penyelenggaraan bangunan-bangunan sekolah, menentukan kurikulum, alat-alat pelajaran, soal-soal dan penyelenggaraan ujian-ujian. Semua ditentukan oleh dan dari pusat. Sedangkan bawahan dan sekolahsekolah hanya merupakan pelaksana-pelaksana pasif.

Organisasi pendidikan yang menerapkan sistem sentralisasi menjadikan kepala sekolah, tenaga pendidik dan tenaga kependidikan dalam melaksanakan tugas dan tanggung jawabnya, serta prosedur pelaksanaan tugas sangat dibatasi oleh aturan-aturan dan instruksiinstruksi dari pusat yang diterima melalui jabatan yang dimiliki oleh atasannya. Sistem sentralisasi semacam ini memiliki identitas pokok yang sangat menonjol yaitu keharusan adanya keseragaman yang sempurna bagi seluruh daerah dilingkungan negara tersebut. Keseragaman itu meliputi hampir semua kegiatan pendidikan, terutama di sekolah-sekolah setingkat dan sejenisnya. Misalnya: keseragaman dalam organisasi sekolah, rencana pelajaran, buku-buku pelajaran, metode-metode mengajar, soal-soaldan waktu penyelenggaraan ujian, dan lain-lain tanpa memperhatikan keragaman dan keadaan daerah masing-masing. Dari penjelasan tersebut, jelaslah bahawa sistem sentralisasi yang seperti itu banyak mengandung kekurangan-kekurangan. Adapun kekurangan yang prinsipal adalah: 1) Administrasi yang cenderung kepada sifat-sifat otoriter dan birokratis. Menyebabkan para pelaksana pendidikan, baik para pegawai maupun kepala sekolah serta guru-guru, menjadi orangorang yang pasif dan bekerja secara rutin dan tradisional belaka. 2) Organisasi dan administrasi berjalan sangat kaku yang disebabkan oleh garis-garis komunikasi antar sekolah dan pusat sangat panjang dan berbelit-belit, sehingga kelancaran penyelesaian persoalanpersoalan kurang dapat dijamin. 3) Karena terlalu banyak kekuasan dan pengawasan sentral, timbul penghalang-penghalang bagi inisiatif setempat, dan mengakibatkan uniformitas yang mekanis dalam administrasi pendidikan yang biasanya hanya mampu sekedar membawa hasil-hasil pendidikan yang sedang atau sedikit (Purwanto, 2005:130).

\section{Struktur Desentralisasi}

Di negara-negara yang organisasi pendidikannya desentralisasi, pendidikan bukan urusan pemerintah pusat, melainkan menjadi tanggung jawab pemerintahan daerah dan masyarakat setempat. Penyelenggaraan pengawasan sekolah-sekolah berada 
sepenuhnya dalam penguasaan daerah. Campur tangan pemerintah pusat terbatas pada kewajiban-kewajiban tentang pemberian tanah subsidi, penyelidikan-penyelidikan, nasehat-nasehat dan konsultasi serta program pendidikan bagi orang-orang luar negeri. Tiap-tiap daerah atau wilayah diberikan otonomi yang sangat luas, yang meliputi penentuan anggaran biaya, rencana-rencana pendidikan, penentuan personel/guru, gaji guru-guru/pegawai sekolah, buku-buku pelajaran, juga tentang pembangunan, pakaian serta pemeliharaan gedung sekolah. Dengan menjalankan struktur organisasi pendidikan secara desentralisasi seperti ini menjadikan kepala sekolah seorang pemimpin profesional dengan tanggung jawab yang luas dan langsung terhadap hasil-hasil yang dicapai oleh sekolahnya. Ia bertanggung jawab langsung terhadap pemerintahan dan masyarakat setempat. Semua kegiatan sekolah yang dijalankannya mendapat pengawasan dan social control yang langsung dari pemerintah dan masyarakat. Penyebabnya karena kepala sekolah dan tenaga pendidikan adalah petugas atau karyawan pendidikan yang dipilih, diangkat, dan diberhentikan oleh pemerintah daerah setempat. Tentu saja sistem desentralisasi seperti ini ada kebaikan dan kekurangannya. Adapun kelebihan yang mungkin terjadi adalah: a) Pendidikan dan pengajaran dapat disesuaikan dengan dan memenuhi kebutuhan setempat. b) Kemungkinan adanya persaingan yang sehat diantara daerah atau wilayah sehingga masing-masing berlomba-lomba untuk menyelenggarakan sekolah dan pendidkan yang baik. c) Kepala sekolah, guru-gurudan petugas-petugas pendidkan yang lain akan bekerja dengan baik dan sungguh-sungguh karena merasa dibiayai dan dijamin hidupnya oleh pemerintah dan masyarakat setempat.

Adapun kekurangannya yaitu: a) Karena otonomi yang sangat luas, kemungkinan program pendidikan di seluruh negara akan berbeda-beda. Hal ini dapat menimbulkan kemungkinan perpecahan bangsa. b) Hasil pendidkan dan pengajaran tiap-tiap daerah atau wilayah sangat berbeda-beda, baik mutu, sifat, maupun jenisnya, sehingga menyulitkan bagi pribadi murid dalam mempraktekkan pengetahuan/kecakapannya dikemudian hari di dalam masyarakat yang lebih luas. c) Kepala sekolah, guru-guru, dan para petugaspetugas pendidkan lainnya cenderung untuk menjadi kariawankariawan yang materialistis, sedangkan tugas dan kewajiban guru pada umumnya lain dari pada kariawan-kariawan yang bukan guru. d) Penyelenggaraan dan pembiayaan pendidikan yang diserahkan 
kepada daerah atau wilayah itu mungkin akan sangat memberikan beban masyarakat setempat (Purwanto, 2005:131). Dari uraian di atas dapat disimpulkan bahwasanya struktur sentralisasi maupun struktur desentralisasi memiliki kelebihan dan kekurangannya. Maka yang lebih baik ialah struktur yang merupakan campuran antara keduanya, yang susunan dan penyelenggaraannya sesuaikan dengan kondisikondisi dan kebutuhan tiap negara secara keseluruhan.

\section{Keefektifan Organisasi}

Mengetahui cara-cara meningkatkan keefektifan organisasi, kelompok, dan individu merupakan tugas utama manajemen. Karena itu aspek yang paling penting dari keefektifannya adalah bagaimana hubungan dalam organisasi itu secara keseluruhan dan keefektifan organisasi selama periode tertentu. Ada beberapa pendekatan keefektifan organisasi menurut para ahli adalah sebagai berikut:

a. Menurut Krakower ada empat pendekatan yang secara umum dilakukan untuk memenuhi keefektifan organisasi yaitu: keefektifan yang dipusatkan oleh hasil ( goal achievement); keefektifan yang penekanannya pada spesifikasi prosedur pengembangan organisasi yang konsisten secara aktual terhadap kebutuhan yang dikelola oleh administrator ( management processes ); keefektifan yang mengembarkan proses internal dengan mempertegas hubungan antar personel organisasi ( organiational climate); dan pendekatan yang memandang keefektifan sebagai keserasian hubungan dilingkungan organisasi maupun di luar organisasi ( environmental adaptation ).

b. Menurut Cameron dan Wetten mengemukakan ada empat pendekatan keefektifan organisasi antara lain, yaitu model sistem sumber daya, model proses internal, model sistem terbuka, dan model kepuasan partisipan. model dan kriteria keefektifan organisasi sedemikian beragam sehingga tidak ada definisi tunggal yang jelas.

Dapat disimpulkan bahwa pendekatan keefektifan organisasi merupakan proses internal dipusatkan pada proses pengelolaan, pengolahan informasi, dan pembuatan keputusan dalam organisasi yang semuanya merupakan pekerjaan manajerial. 


\section{Karakteristik organisasi sekolah yang efektif}

\begin{tabular}{|l|l|}
\hline Komponen & \multicolumn{1}{|c|}{ Karakteristik } \\
\hline Manajemen & $\begin{array}{l}\text { Fokus manajemen didasarkan pada lembaga } \\
\text { pendidikan yang bersangkutan dengan } \\
\text { menekankan pada prosedur pengembangan } \\
\text { organisasi yang aktual dan penggunaan waktu } \\
\text { yang efektif, berpusat pada hasil dan tujuan } \\
\text { yepemimpinan jelas dan terukur, semua anggota memiliki } \\
\text { komitmen dan harapan yang tinggi terhadap } \\
\text { organisasi. k } \\
\text { Berfungsinya komponen- komponen organisasi } \\
\text { secara optimal dan keefektifan menejerial } \\
\text { ditandai kepemimpinan instruksional yang } \\
\text { lugas dan kuat oleh kepala sekolah, kinerja } \\
\text { guru, dan tenaga kependidikan yang profesional } \\
\text { ditopang oleh kemampuan teknologi, } \\
\text { perkembangan lingkungan, peluang yang baik, } \\
\text { kecakapan individu, dan motivasi yang kuat. } \\
\text { Kepala sekolah, guru dan tenaga kependidikan } \\
\text { harus mengambarkan sikap: konsisten, } \\
\text { memiliki komitmen, memiliki integritas yang } \\
\text { tinggi, berfikiran luas dan terbuka, bersikap } \\
\text { jujur, percayadiri, kreatif dan sebagainya, yang } \\
\text { ditandai dengan hubungan perencanaan dan } \\
\text { sikap kolegialitas didukung aturan yang baik, } \\
\text { kuat dan memadai yang dipahami secara me } \\
\text { luas. (Sagala, 2004:77) }\end{array}$ \\
\hline
\end{tabular}

Karakteristik pada tingkat sekolah yang efektif berkaitan erat dengan "manajemen sekolah, kepemimpinan, komitmen, konsistensi tujuan dengan program dan target sekolah, lingkungan strategis internal maupun eksternal, harapan, iklim sekolah dan peran pemerintah. Jadi berdasarkan uraian di atas dapat dipahami karakteristik sekolah yang efektif pada dasarnya meliputi aspek proses persekolahan yang kontribusi terhadap peningkatan kualitas dan nilai tambah hasil belajar siswa. Organisasi sekolah yang efektif didukung dengan manajemen sekolah yang efektif.

\section{Prinsip-Prinsip Organisasi Pendidikan}

Menurut M. Ngalim Purwanto (Purwanto, 2005:18) dalam buku administrasi dan supervisi pendidikan organisasi yang baik 
hendaknya memiliki ciri-ciri atau sifat-sifat sebagai berikut: Memiliki tujuan yang jelas. Setiap anggota dapat memahami dan menerima tujuan tersebut. Adanya kesatuan arah sehingga dapat menimbulkan kesatuan tindak dan kesatuan pikiran. Adanya kesatuan perintah (unity of command); para bawahan hanya mempunyai seorang atasan lagsung: dari pada ia menerima printah atau bimbingan, dan kepada siapa ia harus mempertanggung jawabkan hasil pekerjaannya. Adanya keseimbangan antara wewenang dan tanggung jawab masing-masing anggota. Adanya pembagian tugas yang sesuai dengan skill dan bakat masing-masing, sehingga dapat menimbulkan kerjasama yang harmonis dan kooperatif. Pola organisasi hendaknya relatif permanen, dan struktur organisasi disusun sederhana mungkin, sesuai dengan kebutuhan, koordinasi, pengawasan dan pengendalian. Adanya jaminan keamanan dalam bekerja (security of tenure); anggota tidak merasa gelisah takut dipecat atau ditindak sewenang-wenang. Adanya gaji atau insentif yang setimpal dengan jasa/pekerjaan, sehingga dapat menimbulkan gairah kerja. Garis-garis kekuasan dan tanggung jawab serta hierarkhi tata kerjanya jelas tergambar dalam struktur organisasi.

Sedangkan menurut Sondang P. Siagian, mengemukakan prinsip-prinsip organisasi (Juddin, 2013:2) adalah sebagai berikut: a) Terdapat tujuan yang jelas, tanpa adanya tujuan yang jelas, organisasi dapat diumpamakan dengan sebuah kapal yang berlayar tanpa mempunyai pelabuhan yang akan ditujunya. b) Tujuan organisasi harus dipahamai oleh setiap orang didalam organisasi. Setiap orang didalam organisasi dapat mengetahui tujuan apa yang hendak dicapai dari organisasi tersebut, ada beberapa hal yang dapat mereka laksanakan yaitu: Mengetahui apa yang diharapkan oleh organisasi dari mereka masing-masing, dapat memahami apa yang mereka dapat harapkan dari organisasi. Jika belum singkron, mereka dapat memutuskan apakah berusaha untuk mensingkronisasikan atau tidak, ataukah akan meninggalkan organisasi tersebut.

Tujuan organisasi harus diterima oleh setiap orang dalam organisasi: a) Adanya kesatuan arah (Unity of direction). Artinya bahwa semua kegiata, semua sumber, semua pemikiran, keahlian, waktu dan kemampuan ditunjukkan hanya kepada satu arah, yaitu pencapaian tujuan dengan cara yang seefisien dan seefektif mungkin. b) Adanya kesatuan perintah (Unity of command). 
Hakikat prinsip ini ialah bahwa setiap orang bawahan hanya mempunyai seorang atasan lagsung kepada siapa ia melapor dan pertanggung jawaban dan dari siapa ia menerimaperintah, instruksi, bimbingan, dan pedoman kerja. c) Adanya keseimbangan antara wewenang dan tanggung jawab seseorang. Prinsip ini sangat penting karena wewenang yang lebih besar dari tanggung jawab sering memudahkan penyalahgunaan wewenang tersebut yang akibatnya akan merugikan organisasi. d) Adanya pembagian tugas (Distribution of Work). Struktur organisasi harus disusun sesederhana mungkin. Sederhana berarti sesuai dengan kebutuhan dan memudahkan koordinasi, pengawasan, dan pengendalian. e) Pola organisasi harus relatif permanen. Meskipun struktur organisasi dapat dan memang harus diubah sesuai dengan tuntutan perkembangan, kemajuan/kemunduran, sifat tugas yang lain, karena tujuan terpaksa diubah atau oleh faktor-faktor lain, fleksibilitas dalam penyesuaian itu jangn bersifat mendasar. Oleh karenanya pola dasar struktur organisasi perlu dibuat/sedemikian rupa sehingga tidak perlu sering diubah. f) Adanya jaminan jabatan (security of tenure). Hal ini berarti bahwa kelompok pimpinan tidak boleh memperlakukan bawahannya semene-mena, misalnya dalam bentuk pemecatan tanpa alasan yang kuat. g) Imbalan yang diberikan kepada setiap orang harus setimpal dengan jasa yang diberikan. h) Penempatan orang yang sesuai dengan bakat dan kempuannya (The Right Man on The Right Place).

Dari beberapa pendapat para ahli di atas dapat disimpulkan beberapa prinsip-prinsip dalam organisasi antara lain yaitu harus memiliki tujuan yang jelas, setiap anggota dapat memahami dan menerima tujuan tersebut, adanya kesatuan arah sehingga dapat menimbulkan kesatuan tindak dan kesatuan pikiran, adanya kesatuan perintah, adanya keseimbangan antara wewenang dan tanggung jawab masing-masing anggota, adanya pembagian tugas sesuai dengan kemampuan dan keahlian masing-masing, pola organisasi hendaknya permanen, adanya jaminan keamanan dalam bekerja, adanya insentif yang sesuai dengan pekerjaan dan jasa. Selain prinsip-prinsip di atas, kelancaran suatu organisasi dipengaruhi juga oleh sikap dan sifat kepemimpinan serta human relation yang berlaku didalamnya. 


\section{Pemberdayaan Sekolah}

Dalam dunia pendidikan, pemberdayaan merupakan cara yang sangat praktis dan produktif untuk mendapatkan hasil yang terbaik dari kepala sekolah (manajer), para guru, dan para pegawai. Proses yang ditempuh untuk mendapatkan hasil terbaik dan produktif adalah dengan membagi tanggung jawab secara proporsional kepada para guru. Satu prinsip terpenting dalam pemberdayaan ini adalah melibatkan guru dalam proses pengambilan keputusan dan tanggung jawab. Secara etimologi pemberdayaan berasal dari kata daya yang berarti kekuatan atau mengembangkan kemampuan. Pemberdayaan dapat diartikan sebagai suatu proses menuju berdaya,atau proses untuk memperoleh daya/kekuatan/kemampuan, atau proses pemberian daya/kekuatan/kemampuan dari pihak yang kurang atau belum berdaya. Menurut Cook dan Macaulay (Mulyasa, 2004:32) memberikan definisi pemberdayaan yaitu "alat penting untuk memperbaiki kinerja organisasi melalui penyebaran pembuatan keputusan dan tanggung jawab". Dengan demikian, akan mendorong keterlibatan para pegawai dalam mengambilan keputusan dan tanggung jawab. Dalam dunia pendidikan pemberdayaan ditunjukan kepada para peserta didik, guru, kepala sekolah, dan pegawai administrasi.

Sedangkan menurut Lowe pemberdayaan adalah "kata yang mempunyai arti sifat emotif, atauproses sebagai akibat masalah yang harus dipecahkan, dan untuk memperoleh otonomi, motivasi, keterampilan, untuk tujuan organisasi atau lembaga". Artinya bahwa yang dimaksud dengan pemberdayaan adalah usaha untuk memajukan tingkat individu atau organisasi dan lembaga, dengan manajemen yang cocok dan terkait dengan usaha yang hendak akan diperdayakan, demi tujuan yang akan dicapai. Lebih lanjut menurut Prijono dan Pranarka bahwa pemberdayaan adalah "memberikan atau mengalihkan kekuatan atau kemampuan kepada masyarakat agar individu-individuannya menjadi lebih berdaya" (Mahyudin, 2017:22). Pemberdayaan disini berarti memberikan kekuasaan kepada seseorang atau kelompok untuk suatu tujuan tertentu. Dengan demikian secara singkat dapat dikemukakan bahwa pemberdayaan adalah pemberian atau pembagian kekuasaan atau wewenang kepada orang lain untuk meningkatkan kemampuan yang telah dimilikinya sehingga dia bisa terlibat aktif dalam berbagai kegiatan pengambilan keputusan dan pelaksanaan. 
Dasar pemberdayaan sekolah adalah pengalaman dan pengetahuan masyarakat sekolah tentang keberadaan sangat luas dan berguna, serta kemauan mereka untuk menjadi lebih baik. Proses pemberdayaan sekolah bertujuan memandirikan sekolah agar dapat meningkatkan taraf hidupnyadan mampu mengoptimalkan sumber daya yang ia miliki baik sumber daya alam maupun sumber daya manusia (Mahyudin, 2017:27). Pemberdayaan telah merambah pada berbagai bidang dan aspek kehidupan manusia, termasuk pendidikan, antara lain dikeluarkannya kebijakan MBS sebagai paradikma baru manajemen pendidikan. Manajemen berbasis sekolah merupakan konsep pemberdayaan sekolah dalam rangka meningkatkan mutu dan kemandirian sekolah.

Dengan MBS diharapkan para kepala sekolah, guru dan personal lain di sekolah serta masyarakat setempat dapat melaksanakan pendidikan sesuai dengan kebutuhan, perkembangan zaman karakteristik lingkungan dan tuntutan global. Makna pemberdayaan dalam manajemen berbasis sekolah dimaksudkan untuk memperbaiki kinerja sekolah agar dapat mencapai tujuan secara optimal, efektif dan efisien.

Dalam kaitannya dengan MBS terdapat delapan langkah pemberdayaan (Mahyudin, 2017:33) yaitu: Menyusun kelompok guru sebagai penerima awal atas rencana program pemberdayaan. Mengidentifikasi dan membangun kelompok peserta didik di sekolah. Memilih dan melatih guru dan tokoh masyarakat yang terlibat secara langsung dalam implementasi manajemen berbasis sekolah. Membentuk dewan sekolah, yang terdiri dari unsur sekolah, unsur masyarakat dibawah pengawasan pemerintahan daerah. Menyelenggarakan pertemuan-pertemuan para anggota dewan sekolah. Mendukung aktivitas kelompok yang tengah berjalan. Mengembangkan hubungan yang harmonis antar sekolah dan masyarakat. Menyelenggarakan lokakarya untuk evaluasi.

Adapun karakteristik pemberdayaan menurut Kindervatter yang disebutkan dalam bahasa orang awam (commonalities) (Mahyudin, 2017:35) adalah sebagai berikut:

a. Penyusunan kelompok kecil; pemberdayaan menekankan aktivitas dalam kelompok kecil yang mandiri. Kelompokkelompok yang tumbuh secara alamiah barangkali akan menguat atau tertbentuk dengan basis interes-interes masyarakat. Kualisi juga perlu dibentuk diantaraa para kelompok. 
b. Pengalihan tanggung jawab; dalam manajemen berbasis sekolah terjadi pengalihan dari pemerintah kepada sekolah untuk memperdayaakan diri dan linggkungannya.

c. Pimpinan oleh partisipan; dengan latihan mengontrol atau mengambil keputusan dalam tingkat yang tinggi akan mendorong semua aspek aktivitas organisasi. Kepemimpinan dan pemimpin akan muncul secara alamiah atau dengan dipilih oleh masyarakat sendiri.

d. Guru sebagai fasilitator; guru sebagai fasilitator merupakan pembimbing proses, sumber, orang yang menunjukkan dan mengenalkan kepada peserta didik tentang masalah-masalah yang dihadapi. Komitmen guru dan kepala sekolah sebagai fasilitator adalah terhadap keberhasilan tujuan pemberdayaan dan melaksanakan peran besarnya sebagai pendukung masyarakat agar bisa bekerja secara mandiri.

e. Proses bersifat demokrasi dan hubungan kerja yang luwes.

f. Merupakan integrasi antara refleksi dan aksi; pengalaman dan masalah-masalah yang dimiliki para partisipan akan menghasilkan fokus. Analisa terhadap aksi dan reaksi secara bersama mendorong kearah perubahan dan melibatkan setiap orang pada berbagai resiko pemecahan masalah, perencanaan, pengembangan ketrampilan, dan pertentangan.

g. Metode yang mendorong kepercayaan diri; metode yang digunakan bersifat meningkatkan keterlibatan aktif, dialog, dan aktivitas kelompok secara mandiri.

h. Meningkatkan derajat kemandirian sosial, ekonomi, politik, sebagai hasil proses pemberdayaan kedudukan partisifan dalam hal-hal khusus tertentu.

Sistem desentralisasi (pemberdayaan sekolah) bermakna otonomi. Dalam hal ini otonomi sekolah meliputi pengelolaan kurikulum menjadi bahan ajar, proses belajar mengajar (PMB), pembinaan personel sekolah, manajemen dan pengalokasian anggaran sekolah. Pemberdayaan sekolah, disamping merupakan tuntutan masyarakat, juga merupakan sikaptanggap pemerintah yang mengelolanya dengan prinsip pemberdayaan sekolah (school based management). Adapun prinsip pemberdayaan adalah memberikan otonomi yang lebih luas dalam memecahkan masalah di sekolah. 


\section{Simpulan}

Pembedayaan sekolah dapat dimulai melalui pemahaman yang dimiliki oleh kepala sekolah tentang konsep dari organisasi pendidikan yang terdiri dari pemahaman tentang teori, pengertian, prinsip, pendekatan, betuk, stuktur organisasi, dan unsur-unsur yang terdapat di dalam sebuah organisasi pendidikan tersebut. Hal ini manjadi bagian penting karena organisasi pendidikan yang efektif itu dapat dilihat dari kesesuain antara harapan dan hasil serta kemampuan untuk mencapai hasil tersebut oleh sebuah lembaga. Dan hal ini didasari oleh kematangan konsep yanng harus dimiliki oleh kepala sekolah dan semuan sumber daya manusia (SDM) yang ada pada sekolah tersebut.

Pemberdayaan sekolah merupakan upaya yang dilakukan oleh semua komponen maunpun unsur yang ada pada sekolah serta dapat diberdayakan melalui konsep-konsep yang unggul dan keefektifan serta keberhasilan sekolah. Tujuan pemberdayaan ini adalah bersifat konstruktif untuk kemajuan yang akan dicapai, yang terkait dengan lembaga atau sekolah, artinya penselarasan untuk menyatukan keputusan dan konstribusi sertas killyang baik yang sesuai dengan sekolah dan masyarakat.

Pemberdayaan sekolah juga dapat dilakuan melalui perumusan visi, misi dan tujuan sekolah yang tertuang di dalam rencana induk pengembang sekolah. Diantaranya melalui kegiatan pembelajaran yang didasarakan pada kurikulum dan tujuan pendidikan Nasional yang sesuai dengan kondisi sekolah, kebutuhan daerah seperti adanya kurikulum lokal. Selain itu pemberdayaan sekolah juga dapat dilakukan oleh kepala sekolah melalui kegiatan hubungan kerjasama dengan masyarakat. 


\section{DAFTAR PUSTAKA}

Departemen Pendidikan Nasional 2007. Kamus Besar Bahasa Indonesia. Balai Pustaka, Jakarta.

Erta Mahyudin 2017, Manajemen pemberdayaan sekolah, Madani, Malang.

Hadi, Amirudin dan Haryono 1998. Metodologi Penelitian Pendidikan. Pustaka Setia, Jakarta.

Hidayat, Ara dan Imam Machali 2010, Pengelolaan Pendidikan konsep, Prinsip dan aplikasi dalam Mengelola Sekolah dan Madrasah. Pustaka Eduka, Bandung.

Judding, Magfirah "Prinsip-prinsip organisasi pendidikan: 2013". [Online],Availeble:Http://mgfhyra.blogspot.com/2023/0/prins ip-prinsip-organisasi-pendidikan.html [2018 November 4], hlm. 2

Kadir, Syamsudin 2016. Fitrah Manusi dalam Surat Ar-Rum Ayat 30:2016“.[Online],Availeble:Http://kumpulanidependidikan.b logspot.com/2016/12/fitrah-manusia-menurut-surat-ar-rum. Html [2018 Oktober 17]

Majalah pendidikan.com, "definisi organisasi menurut paraa ahli: $2017 "$ [online],

Availeble: $\mathrm{Http} / \mathrm{www}$.google.com/amp/s/majalahpendidikan.com/definis i-organisasi-menurut-para-ahli. Html [2018 November 8]

Erta Mahyudin, Manajemen pemberdayaan sekolah, (Malang: Madani, 2017),

Mulyasa, E 2002. Manajemen Berbasis Sekolah. PT Remaja Rosda Karya, Bandung

Purwanto, M, Ngalim 2005. Administrasi dan Supervisi Pendidikan. PT Remaja Rosda Karya, Bandung

Sagala, Saiful 2004. Manajemen Berbasis Sekolah dan Masyarakat. PT Nimas Multima, Jakarta

Suryosubroto 2004. Manajemen Pendidikan Di Sekolah. Rhineka Cipta, Jakarta 
80 Fitriyani, Konsep Organisasi Pendidikan,.....

Smith, Abdul, Rahman 2011. An-Nur. Asy-Syifa Press, Semarang Sutapa, Mada 2002. Buku Pegangan Kuliah: organisasi Pendidikan. Pakultas Ilmu Pendidikan Universitas Negeri Yogyakarta, Yogyakarta

Taruna, Tukiman Analisis Organisasi Dan Pola-Pola Pendidikan, (Semarang: Universitas Katolik Sowgijapranata, 2017), hlm. 12

Undang-Undang Republik Indonesia No 20 Tahun 2003. Sistem pendidikan Nasional. Citra Umbara, Bandung

Ibrohim,Bustomi Keefektifan Organisasi Dalam Pemberdayaan Sekolah, Conciencia, (Vol. II. No. 02) 